\title{
Risk factors for nosocomial Acinetobacter bacteremia: a case-control study of intensive care unit patients
}

\author{
Özlem Tunger¹, Gönül Keleş², Şebnem Şenol S', Çiğdem Banu Çetin¹, Horu Gazi', Sümeyra Çoban S², \\ ilkay Aras², Melek Çivi² \\ ${ }^{1}$ Department of Infectious Diseases and Clinical Microbiology Celal Bayar University Faculty of Medicine, Manisa, Turkey \\ ${ }^{2}$ Department of Anesthesiology and Reanimation Celal Bayar University Faculty of Medicine, Manisa, Turkey \\ ${ }^{3}$ Department of Microbiology and Clinical Microbiology, Celal Bayar University Faculty of Medicine, Manisa, Turkey
}

\begin{abstract}
Objective: This study was performed to identify risk factors and to determine the attributable mortality and clinical outcomes of nosocomial Acinetobacter bacteremia in our intensive care unit.

Methods: A retrospective case-control (1:1) study was conducted in a tertiary, academic hospital composed of 300 beds. The control group consisted of 54 consecutive patients with negative blood cultures, matched by sex, age $( \pm 10$ years), primary and secondary diagnosis, operative procedures, and date of admission.

Results: There was a trend for a longer median duration of hospitalization among the patient group compared with the control group ( 25.0 versus 8.0 days; $p=0.001$ ). Patients with Acinetobacter bacteremia had significantly more hemodynamic instability (hypoxia, shock) $(p=0.001)$. We detected that the presence of risk factors such as mechanical ventilation, central venous catheter, anemia, thrombocytopenia, hypoalbuminemia and impairment in creatinine clearance was higher in the patient group than in the control group $(p<0.004)$. Thirty-three $(61.1 \%)$ of the cases died whereas $14(25.9 \%)$ of the controls died $(p=0.001)$. The attributable mortality was estimated as $35.2 \%$. Of the 54 Acinetobacter isolates, $44(81.5 \%)$ were resistant to two or more different antibiotic classes.
\end{abstract}

Conclusion: In critically ill patients, Acinetobacter bacteremia is associated with a significantly increased mortality rate. Central venous catheter insertion, mechanical ventilation, long length of hospital stay and concomitant metabolic disease were risk factors for the presence of bacteremia. J Microbiol Infect Dis 2013;3(4): 157-162

Key words: Acinetobacter spp., intensive care unit, nosocomial bacteremia

\section{Hastane kökenli Acinetobacter bakteriyemisinde risk faktörleri: Yoğun bakım hastalarında bir vaka kontrol çalışması}

\section{ÖZET}

Amaç: Bu çalışma yoğun bakımda gelişen hastane kökenli Acinetobacter bakteriyemilerinde risk faktörlerinin belirlenmesi, hastalı̆̆ın klinik sonuçlarının ve bakteriyemiye atfedilen mortalitenin saptanması için yapıldı.

Yöntemler: Çalışma, 300 yataklı üçüncü basamak bir üniversite hastanesinde retrospektif vaka kontrollü (1:1) olarak gerçekleştirildi. Kontrol grubu; kan kültürü negatif, yaş ( \pm 10$)$, cins, birincil ve ikincil tanıları, operasyon öyküleri ve başvuru zamanları vaka grubu ile eşleşen 54 ardışık hastadan oluşturuldu.

Bulgular: Hasta grubunda ortalama yatış süresi kontrol grubuna göre uzundu (sırasıyla 25.0 ve 8,0 gün, $p=0,001$ ). Acinetobacter bakteriyemisi olan hastalarda hemodinamik instabilite (hipoksi, şok) daha sık gözlendi $(p=0,001)$. Mekanik ventilasyon, santral venöz kateterizasyon, anemi, trombositopeni, hipoalbüminemi ve kreatinin klirensinde bozulma gibi risk faktörleri hasta grubunda kontrol grubuna göre fazlaydı $(p<0,004)$. Kontrol grubunda $14(\% 25,9)$ hasta kaybedilirken, hasta grubunda bu sayı $33(\% 61,1)$ olarak bulundu $(p=0.001)$. Atfedilen mortalite $\% 35,2$ olarak hesaplandı. Ellidört Acinetobacter izolatının 44'ü $(\% 81,5)$ iki ve daha fazla antibiyotik grubuna dirençliydi.

Sonuçlar: Acinetobacter bakteriyemisi özellikle kritik hastalarda mortaliteyi belirgin olarak arttırmaktadır. Santral venöz kateter varlığı, mekanik ventilasyon, uzun hastanede yatış süresi, eşlik eden metabolik hastalıklar bakteriyemi için risk faktörleridir.

Anahtar kelimeler: Acinetobacter spp., yoğun bakım ünitesi, hastane kökenli bakteriyemi

Correspondence: Ozlem Tunger, Department of Infectious Diseases and Clinical Microbiology Celal Bayar University Faculty of Medicine, Infectious Diseases and Clinical Microbiology, Manisa, Turkey Email: otunger@hotmail.com Received: 13.12.2012 Accepted: 07.11.2013

Copyright (C Journal of Microbiology and Infectious Diseases 2013, All rights reserved 


\section{INTRODUCTION}

Acinetobacter species have emerged as important hospital-acquired pathogens causing infectious outbreaks in critically ill patients. ${ }^{1}$ These microorganisms are important because, they are nosocomial pathogens difficult to control, although they are not particularly virulent. The persistence of endemic Acinetobacter strains in the intensive care unit (ICU) seems to be related to their ability for long-term survival on inanimate surfaces in the patients' immediate environment as well as to their widespread resistance to major antimicrobial agents. ${ }^{1,2}$ Changes in health care policies, infection-control practices, antimicrobial use and resistance profile in the past 20 years may have influenced the frequency of these gram-negative organisms among the pathogens associated with hospital-acquired infections. ${ }^{3,4}$ Members of the genus Acinetobacter, particularly Acinetobacter baumanii, are implicated in a wide spectrum of infections, especially nosocomial pneumonia, and bacteremia. Acinetobacter species have recently emerged as the leading cause of nosocomial bloodstream infections in intensive care units. Important increases in mortality rates and duration of ICU stay attributable to Acinetobacter infections have been reported in several case-control studies of critically ill patients..$^{5-8}$ This study was performed to identify risk factors and to determine the attributable mortality and outcome of Acinetobacter bacteremia in our intensive care unit.

\section{METHODS}

\section{Clinical setting}

The study was performed in the Anesthesiology and Reanimation Intensive Care Unit of the Celal Bayar University Hospital in Manisa, Turkey. This ICU has a capacity of 10 patients and serves critically ill patients from the whole hospital.

\section{Patients}

Fifty-four patients who developed nosocomial Acinetobacter bacteremia were matched with 54 control patients without nosocomial Acinetobacter bacteremia from January 2001 to December 2006. This period was chosen because Acinetobacter infections were not epidemic in our hospital yet. Controls were defined as the consecutive patients with negative blood cultures, matched by gender, age (+/- 10 years), primary and secondary diagnosis, operative procedures, and date of admission.

\section{Definitions}

If a patient who presented to the hospital 48 hours ago and / or had a history of hospitalization within the last two weeks prior to their admission to the hospital has Acinetobacter spp growth in at least one blood culture result in addition to the signs and symptoms consistent with bloodstream infections is defined as having nosocomial Acinetobacter bacteremia.

If a patient had more than one episode of Acinetobacter bacteremia during the study, only the first bacteremic episode was included in the analysis.

The physicians to ensure whether it was a causative agent for infection or contamination evaluated each positive blood culture. This decision was based on physical examination findings, body temperature, clinical course and microbiological results. Bacteremia was defined according to the criteria established by the Centers for Disease Control and Prevention. ${ }^{9}$ The presence of contaminants in the blood cultures was defined as a positive culture result without concurrent evidence of infection. These cases were excluded from the analysis.

Bacteremia was considered to be secondary if a clinically and microbiologically documented source (e.g. pneumonia, wound infection, and/or urinary tract infection) of Acinetobacter BSI was identified. Primary Acinetobacter BSI was defined by the absence of an identifiable source of infection, whether an intravascular catheter was in place. Catheter-related bacteremia was diagnosed when the same strain was isolated in blood cultures and semiquantitative culture of a catheter segment (yielding $\geq 15$ colonies) or if there was a clear clinical response after the removal of the catheter. Potential cases were excluded if samples for blood culture were drawn through an intravascular catheter, if any other microorganism was isolated from the same set of blood cultures, or if another microorganism was isolated from cultures obtained during the 72 hours before or 72 hours after Acinetobacter BSI was firstly isolated.

The Acute Physiology and Chronic Health Evaluation (APACHE) II scoring system devised by Knaus et al. was used to assess the severity of an acute illness. ${ }^{10}$ We recorded the APACHE II severity score when the blood culture specimen was drawn. For the control group, these values were calculated when they were included in the study.

\section{Clinical characterization}

The presence of the following comorbid conditions was also documented: neutropenia, immunosuppressive disease, corticosteroid usage, receipt of immunosuppressive agents within 30 days prior to bacteremia, diabetes mellitus, trauma, chronic 
obstructive pulmonary disease and chronic renal failure. Risk factors defined during the ICU stay were as follows: serious surgical operation during 2 weeks before episode, mechanical ventilation (if administered at the time of the blood culture specimen was taken) and the presence of central venous catheter.

Total leukocyte and neutrophil count, platelet count, hemoglobin concentration, erythrocyte sedimentation rate, C-reactive protein, albumin level, and creatinine clearance were recorded when the blood was drawn for culture.

Clinical events, which developed during ICU stay, were cardiopulmonary arrest, respiratory failure, cardiogenic pulmonary edema, sepsis, severe sepsis or septic shock, and multi-organ dysfunction syndrome (MODS), as defined elsewhere. When respiratory failure or shock was present at ICU admission, a 48-h interval during which clinical signs were not present was required to define a new onset of these events.

\section{Microbiological methods}

All blood cultures were processed by microbiology laboratory of our hospital using the BACTEC 9120 blood culture system (Becton Dickinson Diagnostic Instrument System, Sparks, MD, USA) with an incubation period of 5 days. All positive cultures were Gram-stained and sub-cultured on blood agar plates and eosin-methylene blue agar plates for further identification. Confirmation of Acinetobacter identification was performed by using commercial kits (BBL Crystal GP; N/F; ID-Becton Dickinson, USA). Antibiotic susceptibility testing was performed by using the disk diffusion method according to the recommendations of the Clinical and Laboratory Standards Institute. ${ }^{11}$

\section{Statistical analysis}

Continuous variables were described as the mean value with the standard deviation and the median, too. Normality assumption for continuous variables was tested using the Kolmogorov Smirnov test. Differences in the means of normally distributed variables were evaluated by using Student's t-test whereas the Mann-Whitney U-test was used for non-Gaussian variables. Categorical variables were analyzed using the Chi-square test or Fisher's exact test.

A multivariate analysis with logistic regression was performed to identify risk factors independently associated with mortality of the whole group. All $p$ values were 2-tailed; $p$ values less than or equal to
0.05 were considered as statistically significant. All statistical analyses were performed by using Statistical Package for Social Sciences (SPSS Windows version 16.0).

\section{RESULTS}

Patients were included in the analysis and controls were selected in the study period. There was a trend for a longer median duration of hospitalization among cases compared to controls (25.0 versus 8.0 days; $p=0.001$ ). There were no significant differences between the cases and control patients in terms of demographic characteristics and the underlying illness. Demographic and clinical characteristics of the patients with Acinetobacter bacteremia and controls were summarized on Table 1.

The median interval between admission and the Acinetobacter bacteremia was 12.8 (3-65) days (mean, 14.7 days). The most common source of Acinetobacter bacteremia was intravascular catheters (17 cases, $31.5 \%$ ) followed by the respiratory tract (8 cases, $14.8 \%$ ). Only a minority of the patients had other sources, including the urinary tract $(7.4 \%)$ and surgical wounds (3.7\%). There were 23 bacteremic episodes $(42.6 \%)$ in which the source of bacteremia could not be identified.

Fever was the most common sign of Acinetobacter bacteremia (48 cases - [88.8\%]), followed by hemodynamic instability (31 cases - 57.4\%). The patients with Acinetobacter bacteremia had significantly more hemodynamic instability (APACHE II score of $\geq 16$, hypoxia, shock) than did controls. Septic shock was seen in 31 patients in the case group. The subjects in the case group underwent mechanical ventilation and invasive procedure more, suffered anemia, trombocytopenia, hypoalbuminemia more and had lower creatinine clearance levels than did the subjects in control group $(p<0.05)$.

Of the 54 Acinetobacter isolates, 41 were resistant to amikacin, 20 to ampicillin-sulbactam, 49 to piperacillin-tazobactam, and $38(70.4 \%)$ to imipenem. Forty-four $(81.5 \%)$ isolates were resistant to 2 or more different antibiotic classes. Initial empirical antibiotic therapy was instituted for all the case patients, but appropriate antibiotic therapy was considered for only 9 of them (16.7\%). After the results of susceptibility tests were received, treatment was changed appropriately for all the case patients.

Mortality was evaluated during 30 days after the blood culture was performed. Thirty-three $(61.1 \%)$ of the case patients died during hospitalization, compared with $14(25.9 \%)$ of the control patients 
$(p=0.001)$. Attributable mortality is determined by subtracting the crude mortality rate of the controls from the crude mortality rate of the cases. Attributable mortality was $35.2 \%$.
Table 1. Demographic and clinical characteristics of patients with Acinetobacter bacteremia and control patients

\begin{tabular}{|c|c|c|c|}
\hline Variables & $\begin{array}{l}\text { Case patients } \\
\quad(n=54)\end{array}$ & $\begin{array}{c}\text { Control patients } \\
(n=54)\end{array}$ & $\mathrm{p}$ value \\
\hline Age, mean $\pm S D$ & $53.05 \pm 22.30$ & $47.90 \pm 20.58$ & 0,008 \\
\hline Male sex & $39(72.2)$ & $32(59,3)$ & NS \\
\hline Hospitalization duration, median $\left(25^{\text {th }}-75^{\text {th }}\right)$ & $25.0(12,75-40.0)$ & $8.0(5.75-12.0)$ & 0.001 \\
\hline \multicolumn{4}{|l|}{ APACHE II score } \\
\hline$\leq 15$ & $46(85.2)$ & $53(98.1)$ & 0.031 \\
\hline$\geq 16$ & $8(14.8)$ & $1(1.9)$ & \\
\hline Immunosuppressive disease & $31(57,4)$ & $22(40.7)$ & NS \\
\hline Trauma & $13(24.1)$ & $12(22.2)$ & NS \\
\hline Chronic obstructive pulmonary disease & $9(16.7)$ & $5(9,3)$ & NS \\
\hline Chronic renal failure & $3(5.6)$ & $0(0.0)$ & NS \\
\hline Diabetes mellitus & $8(14.8)$ & $6(11.1)$ & NS \\
\hline Steroid usage & $17(31.5)$ & $10(18.5)$ & NS \\
\hline Serious surgical operation & $7(13.0)$ & $3(5.6)$ & NS \\
\hline Central venous catheter & $32(59.3)$ & $54(100.0)$ & 0.001 \\
\hline Mechanical ventilation & $48(88.9)$ & $39(72.2)$ & 0.029 \\
\hline Anemia & $42(77.8)$ & $15(27.8)$ & 0.001 \\
\hline Trombocytopenia & $31(57.4)$ & $16(29.6)$ & 0.004 \\
\hline Hypoalbuminemia & $38(70.4)$ & $25(46.3)$ & 0.011 \\
\hline Decreased creatinine clearance & $17(31.5)$ & $7(12.9)$ & 0.021 \\
\hline Hypoxia & $29(53.7)$ & $10(18.5)$ & 0.001 \\
\hline Shock & $31(57.4)$ & $12(22.2)$ & 0.001 \\
\hline Mortality & $33(61.1)$ & $14(25.9)$ & 0.001 \\
\hline
\end{tabular}

NS=Not significant $(p>0.05), S D=S t a n d a r d$ deviation
Multivariate analysis using a logistic regression model including the variables associated with mortality by univariate analysis $(p<0.05)$ showed that the significant independent risk factors for mortality were older age, receipt of mechanical ventilation, and Acinetobacter bacteremia (Table 2).

Table 2. The risk factors for mortality by multivariate analysis

\begin{tabular}{llll}
\hline Parameters & OR & $95 \% \mathrm{Cl}$ & $\mathrm{p}$ value \\
\hline Acinetobacter bacteremia & 2.63 & $1.02-6.82$ & 0.045 \\
Older age & 4.74 & $1.31-17.15$ & 0.018 \\
Mechanical ventilation & 3.12 & $0.98-9.89$ & 0.05 \\
\hline
\end{tabular}

$\mathrm{OR}=$ Odds ratio, $\mathrm{Cl}=$ Confidence interval

\section{DISCUSSION}

Nosocomial Acinetobacter bacteremia is an important health-care problems leading to increased morbidity and mortality in intensive care units (ICU)., ${ }^{3,12}$ Acinetobacter infections and colonization cause serious consequences in our hospital too. The aim of this matched case-control study was to determine the risk factors affecting the development of Acinetobacter bacteremia in our Anesthesia and Reanimation ICU.

The risk factors playing a role in endemic colonization of Acinetobacter spp and epidemic infections might vary depending on the disease and hospital flora. Main risk factors determined in the previous studies are: bacterial colonization in the patient, the history of broad-spectrum antibiotic usage, prior infection, hyperalimentation, burns involving more 
than $50 \%$ of the total body surface area and the presence of invasive procedures (arterial catheter, abdominal drainages, central venous catheter, mechanical ventilation, nasogastric tube, peripheral vein catheter, pulmonary artery catheter, thoracic drainage, and urinary catheter). ${ }^{7,13-15}$ In our study, we detected that the presence of risk factors such as mechanical ventilation, central venous catheter, anemia, thrombocytopenia, hypoalbuminemia and impairment in creatinine clearance was higher in the patient group than in the control group. Prolongation of hospitalization period also plays a pivotal role in the development of Acinetobacter bacteremia since it leads to an increased colonization of these bacteria in the patient. ${ }^{8,16}$ In the present study, the hospitalization period in the patient group was three times longer than that of in the control group. The difference between two groups was found to be statistically significant.

There are a great number of factors affecting the severity and the prognosis of Acinetobacter bacteremia. In order to evaluate the extent of the disease severity in an intensive care unit, the APACHE II scoring system was used. It was detected that the APACHE II score was significantly higher in the patient group compared with the control group. The same condition is valid for shock and hypoxia variables indicating hemodynamic instability. In multivariate analysis conducted to identify independent risk factors for mortality, the presence of Acinetobacter bacteremia was detected to be the sole independent risk factor. In addition, mechanic ventilation and age were detected to be the independent risk factors for mortality. However, APACHE II score, hypoxia and shock did not constitute independent risk factors.

Resistant bacterial infection is another important challenge in places such as intensive care units where increasing amount of antibiotics are used. Multiple drug resistance is considerably high particularly in Acinetobacter spp.,17-19 The concept of multiple drug resistance represents being resistant to at least two of the following: antipseudomonal cephalosporins/penicilins, antipseudomonal betalactam/beta lactamase inhibitors, carbapanems, fluoroquinolones and aminoglycosides. In our study, we detected that $81.5 \%$ of the species were multiple drug resistant (MDR) and $70.4 \%$ of the species were resistant to carbapenems. Therefore, initial empirical antibiotic therapy was appropriate for only nine patients $(16.7 \%)$. Tigen et al. reported significant results about antibiotherapy for Acinetobacter infections. In this study; age, age greater than 65 years, APACHE II score more than 20 at baseline as well as delayed appropriate administration were found to be associated with mortality. ${ }^{20}$ However, due to the small number of the patients, we could not perform a comparison between the appropriate and inappropriate therapy group.

In clinical studies so far, crude rates of mortality due to Acinetobacter bacteremia have been presented within a wide range (6-57\%). ${ }^{21,22}$ Since true bacteremia cases were enrolled and polymicrobial growths were excluded, we found that crude mortality rate due to Acinetobacter was significantly higher in our matched case-control study than in the control group. Not only the infection but also other risk factors have an effect in on crude mortality rates. It is important to calculate attributable mortality in an attempt to point out the contribution of only Acinetobacter bacteremia to total mortality rate. Studies on attributable mortality in of Acinetobacter bacteremia in intensive care patients reported that the rates ranged from $19 \%$ to $35 \% .{ }^{6,23}$ The overall mortality of Acinetobacter infections was $52.5 \%$ and $72 \%$ during 30 days according to the results of studies from Turkey. ${ }^{19,24}$ In our study, the rate of attributable mortality due to Acinetobacter bacteremia was found to be high (35.2\%). The reason why crude and attributable mortality rates in our study was higher than in other studies might be that the multiple drug resistance was high in species and infection control precautions were not applied appropriately. Besides, such factors as the differences in the studied patient population and the severity of the matched underlying diseases might have had a role in the increased rates. In our study, we aimed to make a one-to-one comparison between the patient group and the control group in terms of age, gender, underlying diseases, and hospitalization time in ICU in order to minimize the effects of interfering factors.

Acinetobacter infections showed an endemic pattern during the study period. Epidemic Acinetobacter outbreaks with an exact identified source have not been reported yet. Unfortunately, despite all the precautions taken, the development of endemic infections has not been completely prevented. This point should be kept in mind while the findings are interpreted and thus the results should not be generalized.

There are several limitations of this study including its retrospective design, a single center experience, a small number of patients, and non-homogeneous therapy. Our retrospective study design is subject to management decisions for patients were uncontrolled.

Each unit or hospital should attempt to identify the responsible risk factors while performing sur- 
veillance for the problematic microorganisms and consider these results in defining hospital infection control policies. In conclusion, strict control precautions, appropriate antibiotic use and appropriate use of invasive procedures are important control methods to prevent the development of Acinetobacter infection.

Acknowledgement: This work was presented in European Congress of Clinical Microbiology and Infectious Diseases, $18^{\text {th }}$ Scientific Meeting 2008, Barcelona, Spain.

\section{REFERENCES}

1. Peleg AY, Seifert H, Paterson DL. Acinetobacter baumanii: Emergence of a successful pathogen. Clin Microbiol Rev 2008;21:538-582.

2. Joly-Guillou ML. Clinical impact and pathogenicity of Acinetobacter. Clin Microbiol Infect 2005;11:868-873.

3. Inan A, Ozgultekin A, Akcay SS, et al. Alterations in bacterial spectrum and increasing resistance rates in isolated microorganisms from device-associated infections in an intensive care unit of a teaching hospital in Istanbul (2004-2010). Jpn $\mathrm{J}$ Infect Dis 2012;65:146-151.

4. Pérez F, Hujer AM, Hujer KM, et al. Global challenge of multidrug resistant Acinetobacter baumanii. Antimicrob Agents Chemother 2007;51:3471-3484.

5. Blot S, Vandewoude K, Colardyn F. Nosocomial bacteremia involving Acinetobacter baumannii in critically ill patients: a matched cohort study. Intensive Care Med 2003;29:471-475.

6. Falagas ME, Bliziotis IA, Siempos II. Attributable mortality of Acinetobacter baumannii infections in critically ill patients: a systematic review of matched cohort and case-control studies. Crit Care 2006; 10:1-8.

7. Playford EG, Craig JC, Iredell JR. Carbapenem-resistant Acinetobacter baumanii in intensive care unit patients: risk factors for acquisition, infection and their consequences. J Hosp Infect 2007;65:204-211.

8. Blot S, Vandewoude K, Colardyn F. Nosocomial bacteremia involving Acinetobacter baumannii in critically ill patients; a matched cohort study. Intens Care Med 2003; 29: 471-475.

9. Garner JS, Jarvis WR, Emori TG, et al. CDC definitions for nosocomial infections. Am J Infect Control 1988;16:128-140.

10. Knaus WA, Drapier EA, Wagner DP, Zimmerman JE. APACHE II: a severity of disease classification system. Crit Care Med 1985;13:818-829.
11. ClinicalandLaboratoryStandardsInstitute(CLSI). Performance standards for antimicrobial susceptibility testing: Twenty-first informational supplement-Volume 31, Number 1, Clinical and Laboratory Standards Institute, Wayne, PA, USA; 2011.

12. Munoz-Price LS, Weisntein RA. Acinetobacter infection. N Engl J Med 2008;358:1271-1281.

13. Garcia-Garmendia JL, Ortiz-Leyba C, Garnacho-Montero J. Risk factors for Acinetobacter baumannii nosocomial bacteremia in critically ill patients: a cohort study. Clin Infect Dis 2001;33:939-946.

14. Jung JY, Park MS, Kim SE, et al. Risk factors for multi-drug resistant Acinetobacter baumannii bacteremia in patients with colonization in the intensive care unit. BMC Infect Dis 2010;10:228.

15. Jang $\mathrm{TN}$, Lee $\mathrm{SH}$, Huang $\mathrm{CH}$, et al. Risk factors and impact of nosocomial Acinetobacter baumannii bloodstream infections in the adult intensive care unit: a case-control study. J Hosp Infect 2009;73:143-150.

16. Garcia-Garmendia JL, Ortiz-Leyba C, Garnacho-Montero J, et al. Mortality and the increase in length of stay attributable to the acquisition of Acinetobacter in critically ill patients. Crit Care Med 1999, 27: 1794-1799.

17. Garnacho-Montero J, Amaya-Villar R. Multiresistant Acinetobacter baumannii infections: epidemiology and management. Curr Opin Infect Dis 2010;23:332-339.

18. Dizbay M, Tunccan OG, Sezer BE, Hizel K. Nosocomial imipenem-resistant Acinetobacter baumannii infections: epidemiology and risk factors. Scand J Infect Dis 2010;42:741746.

19. Metan G, Sariguzel F, Sumerkan B. Factors influencing survival in patients with multi-drug-resistant Acinetobacter bacteraemia. Eur J Intern Med. 2009;20:540-544.

20. Tigen ET, Koltka EN, Dogru A, et al. Impact of the initiation time of colistin treatment for Acinetobacter infections. J Infect Chemother 2013;19:703-708.

21. Pittet D, Tarara D, Wenzel RP. Nosocomial bloodstream infections in critically ill patients: excess length of stay, extra cost, and attributable mortality. JAMA 1994;271:1598-1601.

22. Wisplinghoff H, Bischoff T, Tallent SM, et al. Nosocomial bloodstream infections in US hospitals: analysis of 24,179 cases from a prospective nationwide surveillance study. Clin Infect Dis 2004;39:309-317.

23. Grupper M, Sprecher H, Mashiach T, Finkelstein R. Attributable mortality of nosocomial Acinetobacter bacteremia. Infect Control Hosp Epidemiol 2007; 28:293-298.

24. Ulu-Kılıc A, Ergönül O, Kocagül-Çelikbaş A, Dokuzoğuz B. Predictors of Mortality in Acinetobacter baumannii Bacteremia. Klimik Dergisi 2011;24:162-166. 